\title{
The Socio-Economic Heterogeneity of Rural Areas: Towards a Rural Typology of Poland
}

\author{
Monika Stanny *(D), Łukasz Komorowski (D) and Andrzej Rosner \\ Institute of Rural and Agricultural Development, Polish Academy of Sciences, 72 Nowy Świat St., \\ 00-330 Warsaw, Poland; lkomorowski@irwirpan.waw.pl (Ł.K.); arosner@irwirpan.waw.pl (A.R.) \\ * Correspondence: mstanny@irwirpan.waw.pl; Tel.: +48-(22)-826-94-36
}

Citation: Stanny, M.; Komorowski, Ł.; Rosner, A. The Socio-Economic Heterogeneity of Rural Areas: Towards a Rural Typology of Poland. Energies 2021, 14, 5030. https:/ / doi.org/10.3390/en14165030

\section{Academic Editors: Paweł}

Chmieliński, Mariantonietta Fiore and Peter V. Schaeffer

Received: 6 July 2021

Accepted: 11 August 2021

Published: 16 August 2021

Publisher's Note: MDPI stays neutral with regard to jurisdictional claims in published maps and institutional affiliations.

Copyright: (c) 2021 by the authors. Licensee MDPI, Basel, Switzerland. This article is an open access article distributed under the terms and conditions of the Creative Commons Attribution (CC BY) license (https:// creativecommons.org/licenses/by/ $4.0 /)$.

\begin{abstract}
The paper aims to identify the significant heterogeneity of socio-economic rural development in Poland by identifying different types of rural areas and clarifying the existing diversity. This objective requires the following: (1) defining the rural development in Polish conditions, (2) abandoning the urban-rural continuum concept, and (3) conducting an analysis involving data aggregated from the local administrative units (2173 gminas/communes). The approach is exploratory and is limited to two questions elaborating the main problem related to the scale and character of rural variety: What socio-economic types of rural area are found in Poland? How are they distributed spatially? The statistical procedure is based on Diday's dynamic clouds typological analysis. This yielded seven types of rural areas that exhaust their diversity. The main indicator of the character of the different types is related to the level of deagrarianisation of the local economy. The authors argue that the a priori urban-rural continuum model should be abandoned in favour of a more open approach. Typologies based on local administrative unit data, which avoid a priori assumptions concerning rurality, provide an excellent insight into the heterogeneity of rural areas.
\end{abstract}

Keywords: rural development; socio-economic heterogeneity; LAU; typology; deagrarianisation; rural policy

\section{Introduction}

Rural areas do not develop as autarchic elements, but as an integral part of a country's entire socio-economic system. By its nature, this development is variable over space. Every theory of regional development assumes the existence of territorial differences as an objective fact [1-5]. At the same time, it is assumed a priori that the existence of these differences is undesirable [6-8]. The fundamental questions that come to mind concern the scale and character of this diversity, whether it is functional or dysfunctional, whether rural policies should aim to diminish these differences or accept their existence and select instruments to control the development that account for the socio-economic uniqueness of certain rural regions. In the most general terms, if the goal of socio-economic development is the improvement of residents' well-being, then this goal can be achieved by different means in different areas. Then, cohesion does not have to entail counteracting the diversification of socio-economic structures; it may be understood to mean attaining a similar level of well-being in different structural conditions and functional systems.

With such an approach, identifying the significant features differentiating rural areas and then demonstrating similarities within certain sets of spatial units and differences between sets of various units becomes problematic. In simpler terms: the point is to divide rural areas into several sets that are very similar internally, whereas the differences between the sets are substantial. Each of these sets-rural area types-can be considered as a specific object of socio-economic development policy accounting for its distinctive features. The number of sets to distinguish is only superficially important. In reality, a large number of sets means an increasingly detailed description, taking into account less and less important 
features. The optimal number of sets should, thus, depend on rural areas' significant socio-economic diversity, and not on a study's level of detail.

The present paper steps outside the simplification contained in the "urban-rural continuum", in accordance with the suggestion by Pahl, who argued decades ago [9] (p. 327) that "rather than a continuum it would be better to imagine a whole series of meshes of different textures superimposed on each other, together forming a process which is creating a much more complex pattern". Today the increasing availability of data and the growing analytical capacity enable the specificity of rural areas to be studied in greater depth [10].

We have, thus, undertaken to identify the significant heterogeneity of the socioeconomic rural development in Poland by identifying different rural area types and looking for mechanisms explaining the existing diversity. This objective required the following actions: (1) defining the rural development in Polish conditions, (2) abandoning the urbanrural continuum concept and finding a method using a multi-criteria analysis to categorise the rural area types, and (3) conducting an analysis involving data aggregated at the local administrative unit (gmina/commune) level.

Through its use of Diday's dynamic clouds clustering statistical procedure, the approach to the study is exploratory and may be limited to two questions elaborating the main problem related to the scale and character of rural area variety: What socio-economic types of rural area are found in Poland? How are they distributed spatially? Our aim is not only to distinguish certain rural area types, but also to investigate the complexity of rural areas socio-economic structure.

This approach is in line with the more recent rural typologies in Europe, which have also abandoned the continuum model in favour of a multi-dimensional approach. At the same time, it offers a contribution to earlier research on typologies of rural areas by adding a rural typology for Poland based on data for local administrative units. The study adds to the discussion on the transformation of agricultural rural areas into multifunctional ones, and on the role of agriculture in local economies.

The study's methodology is outlined in a subsequent section. This is preceded by thoughts and observations collected in two sections: on how the approach to rural research evolved, and on the main categories and stages in creating a "typology". Another section presents the research results and characterises the types of rural areas, focusing on their territorial assets and backwardness, which determine the character of local development processes. Finally, we discuss the conditions (reservations) related to conducting such studies and offer some conclusions regarding the issues under consideration. Identifying and gaining a better understanding of the features of different rural areas may provide decision makers with important information for restructuring rural policy frameworks.

\section{From Continuum Studies to Heterogeneity Studies}

The debate on rural policy reveals an obvious duality of approaches to rural development. First, there is the still dominant approach that considers rural areas in opposition to urban areas; on the other hand, their internal heterogeneity is underlined. Some authors $[11,12]$ think that concentrating on the former approach leads to mistaken policies, as these aim to level out the disproportions rather than help adjust to the diversity (of the various types of rural area). OECD (Organisation for Economic Co-operation and Development) countries are increasingly adopting a holistic approach to rural development, focusing on "well-being" in its many aspects. Published in 2019, the Principles on Rural Policy [13] point out that territorially oriented policies should be based on solid evidence and data on an appropriate scale.

In the seemingly endless academic discussion on defining "rural", the fact that rural areas are heterogeneous appears to have been ignored [14-20]. During this discussion, the concept of "rural" was gradually replaced by the concept of "rurality", and rurality, in turn, was connected to a series of socio-economic and demographic problems [21-24]. Theoreti- 
cal and empirical research increasingly focuses on trends typical for a given place $[25,26]$. Importantly, the meaning of rurality can differ depending on the context [8,27-30].

Rural Policy 3.0 indicates the main dimensions in which the rural economy (with its low population density) differs from the urban economy [31]. The first is physical distance from markets and the costs this imposes in terms of transport and connectivity. The second aspect is the importance of competitiveness in regions where the home market is small and the economy is highly specialised in the production of commodities. The third dimension addresses how the specific natural endowment shapes local economic opportunities; thus, also creating unique local economic structures. Reviewing the literature $[8,10,19,20,32]$, we assume that a rural area is a place where people live and make a living, forming local communities, but where, compared to urban areas: (1) both social and economic (especially agricultural) activity is dispersed, (2) less varied social and economic structures are a consequence of poorer competitiveness, and (3) the availability of goods and services (especially public ones) is lower. Such an approach not only highlights the inequality (disproportion) of development between urban and rural areas, but also accounts for varied development between different rural areas.

Early analyses systematising the rural space were based on evaluations of an area's saturation with rural features and the indexation of rural areas. The first attempt was attempted almost 100 years ago by Sorokin and Zimmerman [33], who proposed the urbanrural continuum model. It was on this model that Cloke [21] based the rurality index of England and Wales; he arrived at four categories of rural areas: extreme rural, intermediate rural, intermediate non-rural, and extreme non-rural. Similar studies were later conducted by Cloke and Edwards [34] and Harrington and O'Donoghue [35]. Continuous research on the indexation of rural areas has been conducted in many countries, e.g., Spain [36], Italy [37], China [38], the United States [39], Slovakia [40], etc. (more in: [41]). The general assumption contrived by the urban-rural continuum model is that the socio-economic status of the population decreases with increased distance from larger cities. All of these models assume a one-dimensional relationship between rural and urban areas, dividing the set of spatial units into lower- and higher-level classes based only on differences in a single criterion. However, this has been criticised for its excessive simplification of what is a complex reality $[9,42-44]$.

It needs noting that the study of rurality has evolved substantially. The systematic review of the conceptualisation, operationalisation, and uses of rurality presented by Katherine S. Nelson et al. [24] (p. 363) leads to the conclusion that the approach to this research has "shifted from a basic dichotomy of non-urban areas to a highly complex measure that includes cutting edge data and techniques, pushing researchers and policymakers to consider how this can and should be used for policy and practice in a large number of areas ranging from urban planning to health policy to education and agricultural policy". The Rural Well-being Policy Framework [8] also extends and refines the OECD's earlier work, taking advantage of new analyses to reflect a greater degree of the diversity that exists in rural places for policy purposes. In place of an urban-rural dichotomy, the Rural Well-being Policy Framework identifies three types of rural from the rural-urban continuum: rural inside functional urban areas (FUAs); rural close to cities; and remote rural. The framework identifies the interactions between the three types of rural places and cities, each with stark structural differences, and distinct challenges and opportunities; understanding each of the three types of rural leads to the possibility of shared action and more effectively targeted policy responses. The new framework broadens the scope of analysis. Looking beyond the usual economic factors, it encompasses a multidimensional approach to regional inequalities and the environmental and social dimensions of well-being to deliver a more holistic, people-centred understanding of rural development.

\section{Some Remarks on "Typology" Criteria}

Various classifications and typologies are introduced and used in order to systematise space and capture the inner complexity of a given territory. The difference between these 
two notions requires clarification. The classification of spatial units means a complete and disjoint division of a given area (set of units), inhomogeneous according to certain features, into a number of non-empty subsets that are internally more homogeneous The completeness condition means that each of the studied units undergoing classification has to belong to one of the classes distinguished (where every class has to include at least one spatial unit, in accordance with the non-emptiness condition), while the disjointedness condition means that each unit may only belong to one class [45]. The set is divided on the basis of a similarity relationship, so the following may be used:

(1) Multilevel classification (dividing the set into lower- and higher-level classes solely based on differences in a single criterion);

(2) Multidimensional classification (dividing objects that differ in many aspects simultaneously; then each of these dimensions is treated as a separate variable). Classification means both the action of dividing a set of spatial units and the result of that action.

Typology is an operation that systematises classes, organising them into groups (clusters) that are as homogeneous as possible with respect to the inner structure characterising this class of variables [46]. This is known as the homogeneity criterion. The heterogeneity criterion has to be fulfilled as well, i.e., units belonging to different groups should be as dissimilar as possible. The methods applied in research practice include hierarchical clustering and non-hierarchical clustering [47-49], which use different algorithms and versions of taxonomic methods that result in a disjoint and complete division of objects [50-52].

Every typological analysis has its specificity in terms of the knowledge it provides. It is determined by the objective of a given study and the availability of data. The objective defines the choice of variables to be used, while data availability often restricts the scope of the variables used in the analysis. Irrespective of the criteria serving to distinguish similar areas, it needs remembering that every typology is arbitrary [53-55].

In order to capture the local heterogeneity of rural areas, the analysis has to be performed on granular data $[41,44]$. It is at the lowest level of administrative aggregation (LAU / NUTS5) that we obtain the most detailed picture of spatial diversity. However, it is worth remembering that the LAU is not an internally uniform unit; it often includes specific zones, e.g., having features used for recreation, agriculture, and non-agricultural purposes (e.g., villages concentrating local trade), etc.; as we go "deeper down" into the administrative unit, quantitative methods of analysis lose their viability; qualitative techniques and studies based on GIS (Geographic Information System) become more appropriate [10,41]. This is the level at which the averaging of measurements, inevitable in the case of larger administrative units, is avoided, and we do not lose the possibility of accounting for factors that are important at a local level. The downside of analyses conducted at the LAU level is the poor availability and reliability of statistical data (sensitivity to incidental occurrences), which makes it difficult to describe the socio-economic reality using quantitative methods. In an overview of rural typologies in Europe presented by Copus et al. [53], only 5 out of 25 typologies used granular data covering entire countries. An update of that overview cited by $[24,55]$ indicates that further rural typologies at the NUTS5 (Nomenclature of Territorial Units for Statistics) level have been added over the past decade, e.g.,: Czechia [56,57], Sweden [43], Russia [58], Poland [59], Italy [37], Finland [60], Serbia [61], and Europe [62].

Our review of existing research enabled us to distinguish two main territorial categories of rural area typologies as a spatial order in a local aggregation, i.e., typologies based on granular data. We called them rurality typologies and multidimensional (structural) typologies.

Rurality typologies present the urban-rural continuum, and their origin has been discussed previously. Generally speaking, the criteria for defining rurality are a matter of debate [63], and the resultant continuum is always arbitrary examples [9,21,23,35,36]. The main conclusion suggested by these typologies is that delimitation boundaries largely reflect population density, peripheral location, and the character of economic activity, providing little information on the social and economic structure of rural areas. 
The other group is multidimensional (structural) typologies. These describe the heterogeneity of rural areas through an analysis of the structure of the whole. The important consideration here is not just the spatial distribution of features, but also the relationships between them. The configuration of these relationships reveals the strengths and weaknesses of the trend being studied $[43,54,64,65]$. They can involve the description, for example, of the demographic situation, social capital, education, the labour market, agricultural as well as non-agricultural functions, housing quality, and even environmental quality [24].

The material presented so far indicates the existence of many possible typologies of rural areas. Their identification criteria differ according to the purpose for which they are chosen, their geographical (territorial, regional, national, continental/supranational) scope, their spatial aspect (from NUTS1 to LAU), the number of spatial units in the study, the origin of the variables, the complexity of the indicators used (simple indicators based on primary or secondary data, aggregated indicators), the period covered by the analysis (static or dynamic approach), and the methodological structure (including the method of measuring distances between units, methods of organising them, grouping methods, etc.). However, regardless of the criteria chosen for the procedure (selection of the objective, subject, grouping method), there are many formal stages in building any typology. These are, in order:

1. Formulating the objective of the typology.

2. Selecting the spatial level of the analysis-aggregation of units.

3. Choosing the most appropriate variables.

4. Identifying the most reliable sources of statistical data.

5. Data gathering and processing, calculating the variables.

6. Technical exploration of input data.

7. Checking reliability and knowledge value against the adopted criteria.

8. Final version of the typology.

\section{Methodology}

\subsection{Conceptual Framework and Definition}

In order to determine the significant socio-economic diversity of rural development in Poland, we needed to start by defining the concept that was fundamental for this study. First, we assumed that "rural development" is an analytical category of "socio-economic development"; secondly, it can progress in different directions and depends on local conditions (including previously shaped social and economic structures). It is understood as a process of rural structure evolution towards a resident-friendly social environment enabling residents to obtain socially accepted income from work, the best possible access to public services, and labour markets, giving them a sense of agency and enabling them to fulfil their aspirations. Its measurement should reflect the extent to which residents' needs, thus, defined, are met, or, to put it differently, the degree of advancement of processes that contribute to increased well-being. Of course, the "extent to which needs are met" can be the same or similar in very different conditions, in the presence of very different combinations of economic and social structures. There is no single path along which all rural areas travel in such processes.

This understanding of development was used as the basis for a definition that is not universal but corresponds to the current situation in rural Poland, i.e., it is related to the current stage of changes in rural areas and reflects the rural reality under analysis. Relating this definition to the unique reality of present-day Poland, involved specifying the main areas requiring action and enabling rural residents' well-being to improve, especially measures overcoming the major barriers to development $[8,66]$. It was concluded that these are the barriers related to the diminishing role of agriculture as a source of income, which also implies the development of non-agricultural economic functions and the related labour markets as well as changes in farming aimed at an increased work output $[67,68]$. The shortage of jobs in rural areas causes migration from the countryside, which is highly selec- 
tive and has a negative impact on rural demographic structures. Furthermore, it is taking place parallel to a decreasing demand for labour in farming. In the social sphere, barriers to development emerge in connection with rural residents' relatively low qualifications, a deficit in their sense of agency related to the changes taking place, and a lack of faith in the effectiveness of self-organisation in local communities for solving their problems. Almost half a century of a "real socialism" economy in Poland discouraged rural local communities from showing initiative and taking local affairs into their own hands. The predominant view was that the government would solve all their problems. The collectivist ethic promoted under communism disapproved of individual initiatives and successes, and quite effectively suppressed the emergence of local leaders. Moreover, the official slogan of "socialist rural transformation" and the ideological treatment of peasants as a social group that did not fit in with the Marxist class structure model and was, thus, condemned to disappear, did not contribute to a sense of stability either, and did not encourage social (community) activity [30,69].

At present, agriculture is still a major, and in some regions the predominant, economic function in rural Poland; it employs about $10 \%$ of national labour resources $(22 \%$ of rural resources) and generates 2.6\% of the GDP (Gross Domestic Product) [70]. Of all the postcommunist countries, Poland was the only one that had not undergone collectivisation. However, family farms have their specificity; they are prone to be guided by the evaluation not of their market results, but their benefit to the family [71,72]. In the period of transition from a centrally planned economy to a market economy, after 1989, these farms absorbed some of the people who had lost their jobs as a result of the restructuring of non-agricultural workplaces, pursuing not the maximisation of economic indicators such as the production value as their main goal, but social objectives (chiefly the economic security of family members). This is why the proposed definition of rural development as applied to Polish reality underlines the problem of the deagrarianisation of the economy (the development of non-agricultural jobs, limiting the role of agriculture in rural residents' sources of income) and problems of societal activity, including the self-organisation of local communities.

The application of the concept of "rural development" proceeded in two stages. In stage one, 11 components covering its scope were specified. However, these components were not empirical. In stage two, several empirical indicators were selected for the individual components (Appendix A presents the set of indicators for each component). This was justified by the fact that the components usually corresponded to complex issues impossible to characterise with the help of a simple empirical indicator. In practice, this meant establishing 11 measurement scales to determine the intensity of a given issue in individual spatial units. Next, this was used as the basis for developing the typology of rural areas. The study procedure is shown schematically in Figure 1.

The first of the 11 components was called "spatial accessibility", because it is related to a fundamental quality of rural areas, namely, their spatial extensiveness or dispersion. Development requires the negative aspects of this rural specificity to be overcome; such aspects include problems with the accessibility of the units under consideration ( $\mathrm{gmi}-$ nas/communes) from other areas as well as the accessibility of a given gmina's centre from the other villages within it. We measured this by the distance from major labour markets but also from regional cities, by the accessibility of public transport, etc.

Components 2-6 are related to economic development. The "local economy deagrarianisation" component was especially important here. By deagrarianisation we mean the progressively growing role of non-agricultural functions in providing residents with sources of income, i.e., shifting away from the domination of agriculture in the rural economy. The need for the rural economy's deagrarianisation lies at the foundation of the concepts of multifunctional rural development, lasting development, and sustainable development. This makes it an extremely important component, which is also connected with social development. These connections are generated by the development of public services and increased employment in them, the development of the social and technological infrastructure, and growing opportunities for employment compatible with the aspirations of 
rural residents. The component creates conditions for structural changes within the agricultural function, especially if we consider agricultural over-employment in the family-farm sector (hidden unemployment). Components assessing the situation in the "agricultural sector" have been applied separately from those for the "non-agricultural sector".

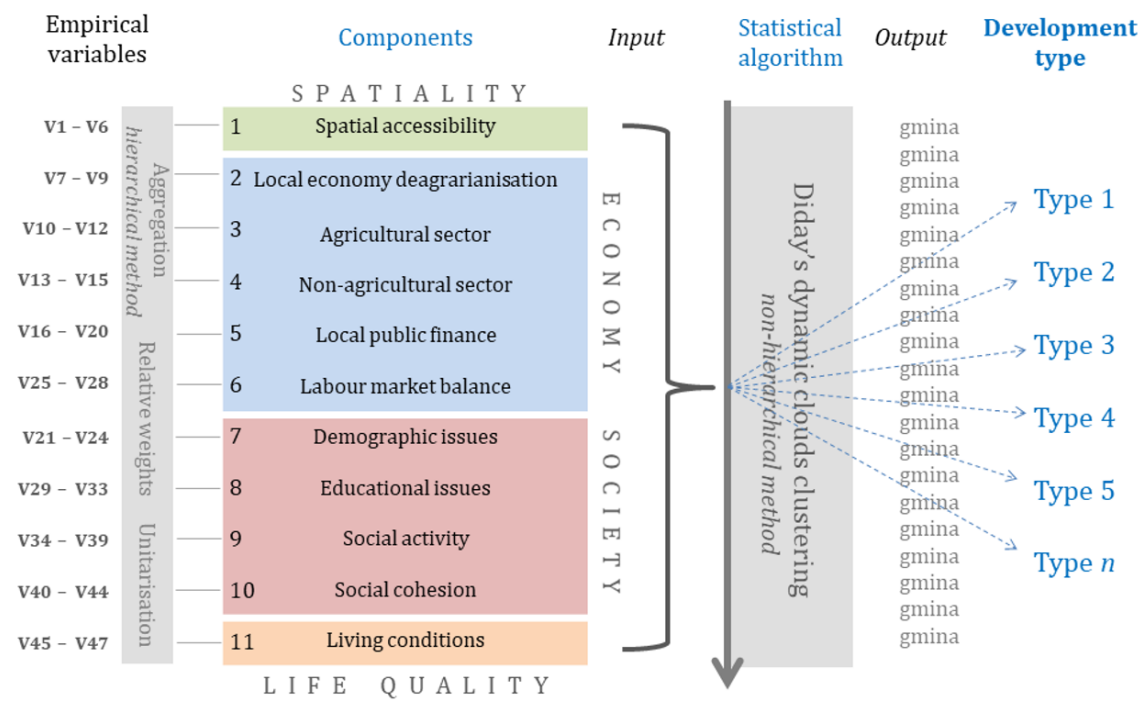

STUDY PROCEDURE

Figure 1. Diagram of the study procedure. Source: own work.

The next component, "local public finance", does not just characterise the gmina budget situation, but is interpreted much more broadly. On the one hand, it shows what budget income the local economy can generate, and, on the other, what the actual capacity for improvement within the gmina's own tasks is, i.e., infrastructure development, improving the availability of public services, etc. In addition, the gmina budget's income provides indirect information on the earlier level of development, especially the value of assets accumulated from earlier periods, with which the gmina is equipped (e.g., infrastructure).

"Labour market balance" is a component covering issues related to the employment of the farming and non-farming population as well as those linked to shaping the structure of labour resources in the gmina. This means that the study considered not only the volume of registered unemployment, but also indicators related to hidden unemployment in agriculture, the ageing of labour resources, and the attractiveness of the local labour market for migrants.

The next group of components, from 7 to 10, describes elements of social development. Among these, "demographic issues" deserve special attention, including how the effects of internal (domestic) migrations influence the make-up of the local community. It is worth noting that mainly young, well-educated, resourceful, and enterprising people migrate. As a result, distinctive changes in the demographic structure take place in the migrants areas of origin: an ageing of the population, a shortage of well-educated people, especially young, educated women. The low level of human and social capital in areas of emigration causes difficulties with the development of non-agricultural functions and a diminished interest in technological and social innovations.

The final, 11th component is "living conditions". This complements the infrastructure elements that were partially covered by "spatial accessibility", some related indicators also being covered by "local public finance". The intention was to interpret living conditions not in terms of quality of life, but in terms of infrastructure for the population (water supply, sewerage, etc.). 


\subsection{Data Sources and Indicators}

The study of the level and structure of socio-economic development was carried out at the level of Local Administrative Units (LAU); thus, covering all 2173 rural gminas and rural areas of urban-rural gminas in Poland. On average, a rural gmina comprises several to a dozen or so villages (depending on their size, which can be very different in different regions) and is inhabited by approx. 7000 people.

The study is distinguished by a unique set of diagnostic features that were the basis for constructing 47 empirical indicators using the 11 components to explain rural development (Appendix A lists the empirical indicators, the data sources and the median). The components were selected with the following criteria in mind: significance for the phenomenon being analysed, accuracy and unambiguity, exhausting the scope of the defined phenomenon, the logical nature of connections, maintaining proportionality, and the availability of information for all the gminas in the study. The data were obtained from the Local Data Bank (BDL) of Statistics Poland (GUS), but also from the unpublished databases of government and communal institutions. These databases include the Agricultural Social Insurance Fund (KRUS), the Central Examination Commission (CKE), the Office of Electronic Communications (UKE), the National Electoral Commission (PKW), the Agency for Restructuring and Modernisation of Agriculture (ARiMR), the Central Register of Vehicles and Drivers (CEPIK) affiliated with the Ministry of the Interior and Administration (MSWiA), the Ministry of Finance (MF); the Ministry of Family, Labour and Social Affairs (MRPiPS); the Ministry of Investment and Development (MIiR), and 16 Marshal Offices (LEADER+ Programme), as well as original primary data collected by gmina polling offices. For instance, the Gmina Survey was conducted using a software tool, and then computer-assisted telephone interviews (CATI) were conducted in every gmina and were the only comparable source on the accessibility of public transport in the country. The data collection was in accordance with Polish law, through access to public infor-mation. All the data were obtained under the Rural Development Monitoring (MROW) pro-ject. The typology results were based on indicators from the last complete MROW 2018 database, while Appendix A lists the latest data already collected for 2019. This study has been conducted cyclically by the European Fund for the Develop-ment of Polish Villages and the Institute of Rural and Agricultural Development of the Polish Academy of Sciences (IRWiR PAN) since 2010. The database was used to pro-duce reports more: $[73,74]$, which discuss the methodology in detail.

\subsection{Method}

All of the empirical indicators underwent a statistical normalisation procedure, which was conducted according to the unitarisation method. They were made comparable, i.e., normalised in the range $(0,1)$. The higher-the-better normalisation was affected by subtracting the lowest number in a given set from its basic value (before normalisation) and dividing the result by the range (the difference between the lowest and highest value in a given set). The procedure for the lower-the-better normalisation was similar, only the number in the numerator was the highest instead of the lowest.

The next stage of the study involved the hierarchical classification of the gminas according to a synthetic measure calculated for each component. Of the many existing methods of linear ordering $[75,76]$, in this study we chose the above-zero unitarisation sums procedure [77], one of the taxonomic patternless methods. In this study, the evaluation of a variable that characterises the $i$-th object is called a "synthetic variable". The synthetic variable obtained from the following Equation (1) assumed values within the range $(0,1)$ :

$$
W_{i}=\frac{1}{n} \sum_{j=1}^{m} m_{i} a_{i j n}^{\prime}
$$


where $a^{\prime}{ }_{i j}$ is the normalised value of the $j$-th feature in the $i$-th object (after the lower-thebetter characteristic was changed to higher-the-better), $n$ is number of objects, and $m_{i}$ is the weight factor of the $i$ feature.

At the stage of calculating the synthetic value of a given component, the empirical indicators were weighted, their weights being based on an analysis of the importance of a given indicator (subjective criterion), and the existence of formal statistical relationships was treated as an extra criterion $[45,78]$.

Next, the synthetic indicators of the 11 components served as the basis for nonhierarchical grouping of the gminas with the aim of forming homogeneous types by similarity of features. The iteration method was chosen for this stage of the study, based on the gravity model proposed and described by Edwin Diday in 1973, called dynamic clouds clustering [79]. In the most general terms, the purpose of this method is to group units in order to form their homogeneous classes (clouds) by internal combinations of the criteria being studied, where, at the same time, the classes are maximally different from one another.

Diday's algorithm is deterministic, it operates in a multidimensional space. In the first step, the units (gminas) form as many classes as they number. The mass of a unit in our study was its population. This distribution of classes defines the inertia to which all the units contribute. The initial cloud (2173 classes $=$ gminas $)$ is then reduced to a new cloud of $k$ class centres, spread around the cloud's global centre. Let us add that this potentially optimal number of subsets ( $k$ classes) was determined using Ward's agglomerative method [48]. Each cloud has its centre of gravity $S$, and the distances between individual points (gminas) are counted as Euclidean distances [80]. The initial (temporary) partition with a specified number of $k$ classes (clouds) has randomly assigned centres of gravity (seeds). Its quality is then improved iteratively, by moving some elements from one class to another if this increases the value of the objective function. Next, the centres of these classes, i.e., their centres of gravity, are calculated and then replace the initial centres (seeds). The assignment procedure is then repeated; the centres are recomputed, and so on. At each iteration, some units change class. The process continues until a final configuration, which cannot be further improved through a local reassignment of units, is reached. The partition obtained is a local optimum: this means that small changes in the allocation of the units to the groups are unable to improve it. Of course, we cannot be sure that the optimal partition (optimum optimorum) has been found, as the method is heuristic. It yields a good-quality partition, but not the absolutely best one. However, for combinatorial reasons, we had to accept this [79].

Once a satisfactory configuration (optimisation phase) was achieved, a profile control procedure began for the individual classes $=$ types. The profile of each class had to be compared with the overall profile in order to assess which variables characterise it more, because of their significantly higher or lower than the overall average values. This analysis was performed in order to explain the structure (complexity) of each type. Hence, the location of individual centres of gravity was determined for clouds $\mathrm{xm}_{(\mathrm{j}, \mathrm{i})}$ (types of similar gminas) in relation to the centre of gravity of the whole system $\mathrm{xg}_{(\mathrm{j})}$. Variable $(\mathrm{j})$ was relative to cloud (i) when the difference $\mathrm{xm}_{(\mathrm{j}, \mathrm{i})}-\mathrm{xg}_{(\mathrm{j})}$ was far from zero (in+ or in-). To estimate the significance, this difference (characterisation of a given type) was compared to the standard deviation $S(j)$. The indicator's value was calculated using Equation (2).

$$
R=\left[\mathrm{xm}_{(\mathrm{j}, \mathrm{i})}-\mathrm{xg}_{(\mathrm{j})}\right] / \mathrm{S}_{(\mathrm{j})}
$$

$\mathrm{xm}_{(\mathrm{j}, \mathrm{i})}$ - average value of variable $j$ in cloud $i$ (type $i$ );

$\mathrm{xg}_{(j)}$ - overall average value of the same variable $j$;

$\mathrm{S}_{(\mathrm{j})}$ - standard deviation of variable $j$.

The strength of the individual variables' influence on development processes was also studied with the help of correlation (mutual dependence of features). It was assumed that the coefficient exploring the relationship between empirical variables would be based on 
Pearson's linear correlation (r). All of the empirical variables were described on quotient scales, i.e., scales that are logically stronger compared to those describing synthetic measures. These, in turn (i.e., the measures of the components), were described on ordinal scales. This was why nonparametric statistics were used: Kendall's tau (T), which should be interpreted in terms of probability $[81,82]$.

\section{Results: Typology of Rural Areas}

The analysis based on Diday's dynamic clouds clustering yielded seven types of unit with a significant diversity of sets and, at the same time, with a similar socio-economic development structure in a given type of gmina (and also uncovering the profile of each type); see Figure 2. We, thus, obtained a description of rural areas from the point of view of combinations of features using socio-economic development (i.e., the 11 components). This method enabled us to indicate the weak and strong points of development, areas of economic activity and societal activity that relatively stand out from the national averages, and also to point to areas requiring intervention from public policy, especially regional policy, rural policy and cohesion policy.

The profiles of the types obtained in the study were developed according to the principle outlined in the previous section (see Equation (2)). To facilitate the analysis of the distance between the parameters of the centres of gravity of a given subset (type) and the whole system, we introduced an interpretative simplification, normalising the distance parameters by assuming the value $=100$ for every component and for the whole group of gminas, treating it as the average value for the whole set ( 2173 gminas). The greater than 100 was the indicator for a given type of component, the more favourable was the situation; conversely, the lower than 100 was the indicator, the less favourable was the situation. The results are presented in Table 1 . The strength of influence of individual components on one another was explained by the Kendall's tau correlation coefficients shown in Table 2.

Table 1. Socio-economic characteristics of the types.

\begin{tabular}{|c|c|c|c|c|c|c|c|c|}
\hline Components of Socio-Economic & \multicolumn{7}{|c|}{ Type } & \multirow{2}{*}{ Overall Profile } \\
\hline Development & & 2 & 3 & 4 & 5 & 6 & & \\
\hline \multicolumn{9}{|c|}{ Type characteristics } \\
\hline Spatial accessibility & 88 & 91 & 99 & 105 & 99 & 113 & 118 & 100 \\
\hline Deagrarianisation of the local economy & 47 & 97 & 72 & 112 & 111 & 144 & 169 & 100 \\
\hline Farm sector & 102 & 121 & 96 & 75 & 110 & 91 & 101 & 100 \\
\hline Non-farm sector & 75 & 93 & 88 & 98 & 109 & 119 & 150 & 100 \\
\hline Local public finance & 58 & 83 & 73 & 76 & 112 & 151 & 224 & 100 \\
\hline Demographic issues & 82 & 100 & 93 & 106 & 106 & 105 & 126 & 100 \\
\hline Labour market balance & 86 & 85 & 97 & 104 & 105 & 112 & 129 & 100 \\
\hline Educational issues & 85 & 87 & 101 & 106 & 97 & 117 & 125 & 100 \\
\hline Societal activity & 84 & 88 & 98 & 103 & 101 & 116 & 133 & 100 \\
\hline Social cohesion & 82 & 80 & 95 & 104 & 103 & 120 & 143 & 100 \\
\hline Living conditions & 75 & 99 & 89 & 100 & 109 & 116 & 131 & 100 \\
\hline \multicolumn{9}{|c|}{ General characteristics } \\
\hline Number of gminas & 474 & 381 & 449 & 161 & 433 & 227 & 48 & $\sum 2173$ \\
\hline$\%$ of gminas & 22 & 18 & 21 & 7 & 20 & 10 & 2 & $\sum 100$ \\
\hline Weight \% (population) & 12 & 14 & 17 & 10 & 23 & 19 & 5 & $\sum 100$ \\
\hline Population density (people/sq. km) & 36 & 30 & 56 & 111 & 49 & 107 & 159 & M52.4 \\
\hline
\end{tabular}

Explanatory note: the colors indicates the type, as in Figure 2; the lowest evaluation of a component in the set of types is highlighted in red; the highest evaluation is highlighted in blue. Source: own work.

Table 2. Kendall's tau correlation matrix.

\begin{tabular}{|c|c|c|c|c|c|c|c|c|c|c|c|}
\hline Component & 1. & 2. & 3. & 4. & 5. & 6. & 7. & 8. & 9. & 10. & 11. \\
\hline 1. Spatial accessibility & 1 & & & & & & & & & & \\
\hline 2. Deagrarianisation of the local economy & 0.274 & 1 & & & & & & & & & \\
\hline 3. Farm sector & -0.154 & -0.025 & 1 & & & & & & & & \\
\hline 4. Non-farm sector & 0.200 & 0.484 & -0.024 & 1 & & & & & & & \\
\hline 5. Local public finance & 0.234 & 0.477 & 0.052 & 0.410 & 1 & & & & & & \\
\hline 6. Demographic issues & 0.184 & 0.380 & 0.059 & 0.304 & 0.202 & 1 & & & & & \\
\hline 7. Labour market balance & 0.275 & 0.257 & -0.180 & 0.321 & 0.289 & 0.348 & 1 & & & & \\
\hline 8. Educational issues & 0.244 & 0.318 & -0.225 & 0.252 & 0.289 & 0.108 & 0.265 & 1 & & & \\
\hline 9. Societal activity & 0.174 & 0.250 & -0.159 & 0.200 & 0.314 & 0.159 & 0.294 & 0.246 & 1 & & \\
\hline 10. Social cohesion & 0.284 & 0.317 & -0.217 & 0.357 & 0.380 & 0.239 & 0.587 & 0.381 & 0.336 & 1 & \\
\hline 11. Living conditions & 0.274 & 0.517 & 0.082 & 0.421 & 0.438 & 0.436 & 0.348 & 0.238 & 0.245 & 0.403 & 1 \\
\hline
\end{tabular}




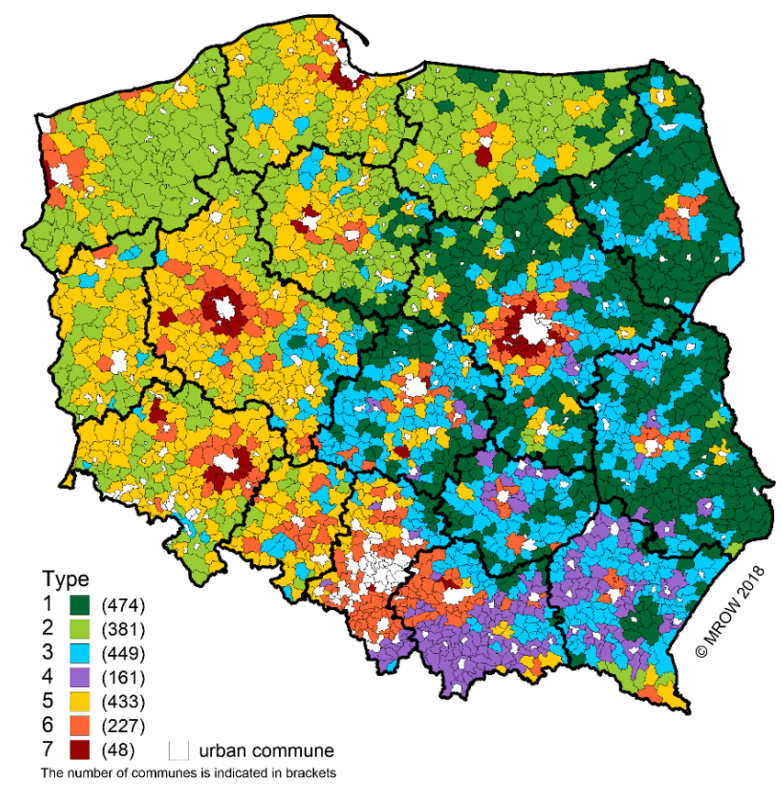

Figure 2. Spatial distribution of the types of rural areas. Source: own work.

\subsection{Rural Areas Dominated by Traditional Agriculture}

Type one gminas were mainly found in Poland's eastern borderland and in the peripheral areas in the regional division of the country into Central and Eastern Poland. They accounted for $22 \%$ of all the gminas in the study but were home to just $12 \%$ of the country's rural population. Demographically, they are characterised by a relatively high share of the elderly population and a relative shortage of young women (compared to the number of young men). This is the effect of a long-term process of young people's migration to cities and suburban areas [83]. The local labour market has a low supply as well as a low demand for labour, which produces an effect of apparent balance [84].

The deagrarianisation of the economy in these gminas is much less advanced than the average for rural Poland. They were sharply distinguished by unfavourable characteristics not only of the population's demographic structure, but also living conditions, a weak non-agricultural economy, and a poor assessment of local public finance. Agriculture has a very high share in the economy. The predominance of agriculture and the weakness of the non-agricultural sector means that non-agricultural jobs are largely concentrated in local administration institutions and those providing public services (healthcare, education, police, etc.), so the government continues to be the most important non-agricultural employer in these areas. This is a region which historically (throughout the 19th century and until the end of World War I) was under the jurisdiction of the Russian Empire [85]. The current spatial diversity has been heavily influenced by the fact that, between 1795 and the regaining of independence in 1918, Poland was split between three powers: Prussia, Austria-Hungary, and Russia. Each of the partitions developed under a different political, legal, and economic system. Consequently, three types of rural areas developed, differing in many features, such as agrarian structure, settlement structure, village development patterns, providing elements of infrastructure as well as education structure, demography, and population density, which are still noticeable in the current socio-economic structure $[73,86]$. Rural areas that used to lie in the former periphery of the Russian Empire continue to report the lowest level of socio-economic development (more in: [87]).

The only component assessed slightly above average in type one gminas was agriculture. In these areas this was based on families. The literature describes these family farms as "peasant farms", where production functions are permanently tied to the peasant family's way of life $[67,72,88]$. However, in the long-term, the high proportion of family farming in the local economy will not enable a sufficiently high enough population to be maintained in this type of gmina; even today, most of their populations are diminishing 
as a result of a negative birth rate as well as a steady and highly selective migration [89]. Type one gminas might be described as a rural region with an especially high proportion of traditional family farming in the local economy.

\subsection{Rural Areas Dominated by Large-Scale Agriculture}

Type two was formed by $18 \%$ of gminas, concentrated almost exclusively in Poland's Western and Northern Territories, especially in the northern part of this region (i.e., areas incorporated into Poland after 1945). These gminas have almost $14 \%$ of the rural population, while the population density is the lowest in the country. The distinctive feature of this type of gmina is the relatively high proportion of large farms, which emerged following the restructuring of PGRs (Państwowe Gospodarstwo Rolne = State Agricultural Farms) and represent different forms of legal entity; their common feature is that, unlike family farms, they use hired labour. A State Agricultural Farms were formed after World War II and abolished in 1992. These farms were a form of collective farming in the People's Republic of Poland, similar to the Soviet sovkhoz and the East German Volkseigenes Gut. Today, family farms in this region are relatively large, especially those that once adjoined the subsequently restructured PGRs and, thus, had the opportunity to purchase or lease state-owned land. Within a short time, the average area of a family farm here increased from about 10 to 30 hectares.

Gminas of this type are characterised by a high share of agriculture in the economy, but-compared to type one-a much more favourable demographic situation (especially by age and sex). Compared to other regions of Poland, the residents of this type of gmina have a polarised education structure, but, in general, their social capital was assessed as being below the national average. Typical trends in this type include people escaping into economic inactiveness and pressure on welfare assistance [90]. In the briefest terms, type two gminas might be described as having a relatively high number of large farms and as yet not fully resolved problems stemming from PGR restructuring. In particular, these problems include low qualifications of unemployed former PGR workers as well as centres of poverty concentrated in housing estates (blocks of flats) built for PGR workers and functionally connected with a type of state farming that no longer exists. They are also related to the collapse of the extensive welfare functions found at PGRs (state-farm shops, transport, crèches, and kindergartens, etc. for the workers and their children) [91].

\subsection{Rural Areas Dominated by Agriculture: Intermediate}

Type three accounted for $21 \%$ of gminas, where $17 \%$ of the rural population live, while the population density is close to the median for rural Poland. Almost all of these types of gmina are in Central and Eastern Poland, and practically never border big cities. In certain regards, these gminas are similar to type one, but differ in their greater accessibility (close to the average for the whole set under consideration) as well as a higher level of deagrarianisation of the local economy, although this is lower than the national average. The level of non-agricultural development and the characteristics of local public finance are more favourable than in type one, but still remain relatively low. The local economy is dominated by agriculture, which is based on family farming, although this is less traditional (peasant-like) in character than in type one gminas.

These gminas are characterised by a more favourable labour market, better living conditions, and fewer demographic problems than type one. In many respects, the characteristics of these gminas are close to the national average; also spatially, they came between peripheral areas (type one) and suburban areas whose development takes advantage of the proximity of urban areas. For these reasons, type three gminas can briefly be described as rural areas that are intermediate between areas with centres of development and the peripheries in Eastern and Central Poland. 


\subsection{Rural Areas with Dispersed Agriculture and Multiple Sources of Income}

Type four covered just $7 \%$ of gminas, but accounted for almost $10 \%$ of Poland's rural population. Most gminas of this type are concentrated in South-Eastern Poland. They are characterised by large village populations, many of them exceeding 1000 residents and some even 5000 (the average size of a rural locality in Poland is about 360 residents). These are areas with a relatively high population density (double the national rural average), but also a highly fragmented farm structure. The average farm size in many of these gminas is around 3 hectares, meaning the farms are four times smaller than the national average. Furthermore, these small farms are composed of many small plots that do not border on one another. On the other hand, in these types of farm there are very few families where farming is their main source of income [73]. The relatively dense urban network has meant that the widespread model in this region involves daily commuting and treating the farm as a supplementary source of income [92,93].

In short, type four gminas are characterised by agrarian fragmentation and multiple sources of income in farming families. In these gminas, farms are losing their importance as the family's source of income, while the deagrarianisation of the economy is not connected with the concentration of land, but often with the disappearance of agriculture.

\subsection{Multifunctional Rural Areas: Balance of Sectors}

Type five comprised rural areas in Western Poland, which were historically under the jurisdiction of the Kingdom of Prussia until the inter-war period. A small number of gminas of this type are also found in eastern Poland, but in this case they form a base for medium-sized towns that have not yet developed a suburban area that would be closely bound to them.

There are 433 gminas of this type, $20 \%$ of the overall number of units in the study. They account for about $23 \%$ of the rural population. These gminas are distinguished by a relatively high level of development of both the agricultural and non-agricultural functions (compared to other areas that do not adjoin large urban centres). As a result, the local labour markets are relatively well developed. The social characteristics of this region are also distinctive, which is connected with the relatively early introduction (in the 19th century) of compulsory education as well as a tradition of collaboration to resolve local problems. Type five gminas receive above-average (or average) assessments for all the socio-economic components, which means their development is harmonious. Despite relatively advanced non-agricultural development, as agriculture reduces its share in the socio-economic structure, it also undergoes modernisation. This type might, therefore, be described as multifunctional gminas with a balance between the agricultural and nonagricultural sectors.

\subsection{Suburban Rural Areas with Reduced Agriculture}

Type six made up $10 \%$ of the gminas in the study and $19 \%$ of the overall rural population. In general, one might say these are gminas of the second ring around big cities and the first ring in the case of medium-sized ones. They are also concentrated around the Katowice conurbation, i.e., the Upper Silesian Industrial Region, within which they are located in the spaces between industrial cities.

This type of gmina is distinguished by relatively good transport connections with the central city, which forms the labour market for gmina residents, and a reduced agricultural function. Some villages in this type of gmina, especially those near big cities, are turning into second-home settlements for urban residents and developing recreational functions. In demographic terms, these are immigration areas and, thus, are characterised by a population with a favourable age and education demographic. The residents' connection to the city through jobs results not only in their relative affluence, but also, with the current tax systemin the favourable situation of the gminas in terms of local public finance. Generally speaking, taxes connected with farming are much lower than those for other sectors of the economy. Among other things, income from work in agriculture is not covered by personal 
income tax. Consequently, revenue for local budgets, which depends on taxes paid in a given local area, is relatively smaller in units with a large proportion of agriculture in the economy.

\subsection{Highly Urbanised Rural Areas}

There were just 48 (2\%) type seven gminas, but $5 \%$ of the rural population live there. These are gminas in the first ring around the biggest cities, and a few individual gminas in the case of medium-sized cities. They are largely the effect of cities spreading beyond their administrative boundaries. Some localities in these gminas have lost their rural character and have turned (or are turning) into housing estates, sometimes even city districts. Others are developing service functions for the urban economy: warehouses, shopping centres, etc. In general, rents (or land prices) are lower outside the administrative boundaries of cities, which is why giant shopping centres are located just outside them, along main transport routes. In type seven gminas, agriculture is dying out or turning to the production of flowers, ornamental plant seedlings, spring vegetables, etc., for the urban market [94].

Due to the migration of residents from city centres, which mainly involves the wealthy and educated urban population, these gminas are not only in a good financial situation, but also have affluent residents. As a result of such migration, housing estates of an unequivocally urban character are appearing in environmentally attractive areas with easy commuting to the city centre [95]. In a generalisation, type seven rural areas are developing residential and service functions, while the reduction in traditional rural functions, including agriculture, is well advanced. Hence, the relatively most favourable assessment of all components with the exception of agriculture is concentrated in this particular type-see Table 1 .

It is clear that types six and seven were gminas whose level of development was closely linked to the character of their location in relation to urban markets, while they differed in the extent of their transformation towards urbanisation.

\section{Discussion and Conclusions}

We usually assume that the spaces where people live and work are organised according to a country's existing territorial division into smaller areas (in Poland: województwo/province, powiat/county, and gmina/commune). However, it needs remembering that such a division is only a convention, even if a very useful one. The development of rural areas is distributed unevenly across the administrative grid. This diversity is reflected in the set of territorial units differing in the existence and intensity of features typical of that development and in the relationships between those features. Structural and functional ties in social and economic activity over a given space enable sets of units sharing the same features to be distinguished: we call them types. Within the issues considered here, this system of typologically unified areas is independent of the (administrative) regional system. The typology boundaries cut across administrative ones [43]. When development policies are being developed at the national or regional level, it is necessary to acknowledge the heterogeneity of regions (provinces) in order to work out a well thought-out policy targeted at specific places (rural areas) [25].

Various classifications and typologies of rural areas that take account of socio-economic characteristics are developed depending on research goals and perspectives, so they have no inherent specificity of their own. Moreover, the criteria adopted and the methods used to analyse rural areas determine the picture of their spatial diversity, which can, thus, be varied. Hence, the many empirical examples (Section 2). Due to the existence of differences across each country, the heterogeneity of rural areas should be studied for every country separately and, wherever possible, at the lowest territorial level [10]. Furthermore, depending on the assumed goal of an analysis, rural typologies for one country can have very different properties, by which they can be distinguished from one another. Examples include various Czech typologies [56,57], Italian [96] as well as Polish ones [59] and the present typology. 
One of the main conclusions to be drawn from recent research on changes in the countryside is that rural areas are socio-economically diverse [8,31]. Compared to similarly detailed rural typologies (see Section 3), the socio-economic content of the present typology was different (which does not come as a surprise), although the geographical pattern was similar in the sense that it suggested a dual polarisation process in rural development. First, the types of area in every region were distributed relatively concentrically (the closer to regional centres, the more favourable are the rural development characteristics). Traditional agriculture (one), intermediate (three), and urbanised (six and seven) types are very closely linked to the centre-periphery order. Secondly, relatively monofunctional agriculture (one and two), multiple sources of income (four), and multifunctional (five) types are related to an order resulting from history, where types one, four, and five are linked to diversity that emerged in the 19th century, and type two (with the domination of large-scale agriculture) to the border changes following World War II. The location of this last type coincided with "post-PGR areas". In summary, the rural area types in Western Poland have relatively more favourable development characteristics.

With reference to popular academic topics such as "long-term rural vision" [97-99] or "rural decline" $[100,101]$, this study contributed to the discussion on the various potentials of rural areas, the directions of the transformation of agricultural rural areas into multifunctional ones, and the role that agriculture plays in local economies. The socio-economic content covered in the typology proves that agriculture continues to be a key feature of local socio-economic structures, influencing the spatial delimitation of rural areas in Poland. The main indicators of the character of the different rural area types related to the extent of deagrarianisation of the economy and the character of the agrarian structure. The main conclusions are as follows:

- The domination of traditional agriculture inhibits the social and economic development of rural areas.

- Rural areas, even those situated far from urban centres, can achieve an average level of development, provided their development is multifunctional.

- On farms with numerous sources of income, the agricultural function diminishes.

- The deagrarianisation process of a local economy may be successful or not. Its success in terms of the level of socio-economic development depends on whether agriculture is replaced by other economic functions, or the population becomes reliant on nonearned sources of income.

Furthermore, the study showed the benefits of a different kind of territorial typology, which, instead of classifying areas by their level of rurality or by their overall socioeconomic results, sought to capture the differences in the set of territorial assets that define the character of local development processes and their relative success. We consider that even greater practical benefits will be achieved when the analysis is carried out in a dynamic manner. Such a study should reveal certain development scenarios followed by municipalities and bring us closer to answering the question why some municipalities develop and others do not.

The study's concept of measuring the diversity of territorial development with a wide range of empirical data as well as its repeatability pointed to the application potential of this research. Thanks to its features, this can be a diagnostic tool useful for rural development policies, providing reliable information on the effects of earlier measures, as well as suggestions for future decisions. The results of this study were made available to the OECD as important material in the Rural Policy Review Poland 2018 [66]. The logic of the study, together with the statistical data, was also used in the evaluation of the cohesion policy's effect on rural development in Poland [102]. Such a tool is no less important for the work of local authorities, among other things enabling them to obtain information useful in assessing the competitive advantages of territorial units, comparing a unit's position with that of others, and in strategic planning and management [103]. It is, thus, an example of a typology of rural areas that is based on indicators representing a number of territorial 
assets and challenges and which has significantly expanded the evidence base for rural policies (more in: [73,74]).

Author Contributions: Conceptualisation, M.S.; methodology, M.S. and A.R.; validation, M.S. and Ł.K.; formal analysis, M.S. and Ł.K.; investigation, M.S., Ł.K. and A.R.; resources, M.S. and Ł.K.; writing—original draft preparation, M.S., Ł.K. and A.R.; writing—review and editing, M.S., Ł.K. and A.R.; visualization, Ł.K.; supervision, M.S. All authors have read and agreed to the published version of the manuscript.

Funding: This research is part of the Rural Development Monitoring (MROW) project, funded by the European Fund for the Development of Polish Villages-Counterpart Fund (EFRWP)—, under the agreement of 31 December 2016 between the European Fund for the Development of Polish Villages - Counterpart Fund (EFRWP)—and the Institute of Rural and Agricultural Development, Polish Academy of Sciences (IRWiR PAN) within the framework of the programme "Development Initiatives Forum".

Institutional Review Board Statement: Not applicable.

Informed Consent Statement: Not applicable.

Data Availability Statement: http://www.irwirpan.waw.pl/538/aktualne-projekty-badawcze/ monitoring-rozwoju-obszarow-wiejskich (accessed on 15 August 2021); data available on request, after its approval by the authors.

Conflicts of Interest: The authors declare no conflict of interest. The funders had no role in the design of the study; in the collection, analyses, or interpretation of data; in the writing of the manuscript, or in the decision to publish the results.

\section{Appendix A}

Table A1. List of Empirical Indicators Used in the Rural Development Monitoring (MROW).

\begin{tabular}{|c|c|c|c|c|c|}
\hline Components & Number of Indicator & Empirical Indicators & Spatial Unit ${ }^{a}$ & Median (2019) & Data Provider ${ }^{b}$ \\
\hline \multirow{6}{*}{ 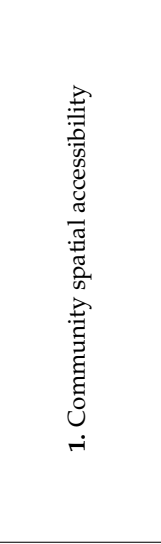 } & W1 & $\begin{array}{l}\text { Average time needed to reach the capital of } \\
\text { voivodeship }\end{array}$ & M_W & $70 \mathrm{~min}$ & Gmina Survey \\
\hline & W2 & $\begin{array}{l}\text { Average commuting time to the nearest } \\
\text { powiat (district) town that has a significant } \\
\text { role for the local labour market }\end{array}$ & M_W & $20 \mathrm{~min}$ & Gmina Survey \\
\hline & W3 & $\begin{array}{l}\text { The percentage of gmina villages connected } \\
\text { by public transport (bus stop or railway } \\
\text { station), with the exception of student } \\
\text { transport }\end{array}$ & M_W & $83.3 \%$ & Gmina Survey \\
\hline & W4 & $\begin{array}{l}\text { The percentage of villages accessible by a } \\
\text { paved road }\end{array}$ & M_W & $100 \%$ & Gmina Survey \\
\hline & W5 & $\begin{array}{l}\text { The total number of registered passenger } \\
\text { cars per } 100 \text { inhabitants }\end{array}$ & M_W & 61.5 & $\begin{array}{l}\text { Central Register of } \\
\text { Vehicles and Drivers } \\
\text { (CEPIK) }\end{array}$ \\
\hline & W6 & $\begin{array}{l}\text { The percentage of cars manufactured } \\
\text { before } 2009 \text { in the total number of } \\
\text { registered vehicles }\end{array}$ & M_W & $90.4 \%$ & $\begin{array}{l}\text { Central Register of } \\
\text { Vehicles and Drivers } \\
\text { (CEPIK) }\end{array}$ \\
\hline \multirow{3}{*}{ 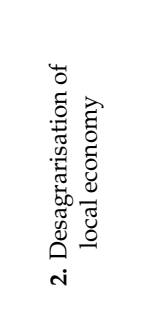 } & W7 & $\begin{array}{l}\text { The percentage of non-agricultural } \\
\text { businesses in the total number of } \\
\text { businesses }\end{array}$ & M_W & $36.6 \%$ & $\begin{array}{l}\text { Ministry of Finance } \\
\text { (MF) and the Agency } \\
\text { for Restructuring and } \\
\text { Modernisation of } \\
\text { Agriculture (ARiMR) }\end{array}$ \\
\hline & W8 & $\begin{array}{l}\text { CIT and PIT revenues to the gmina's budget } \\
\text { per PLN } 1 \text { of agricultural tax revenue }\end{array}$ & M_W & 8.6 PLN & Local Data Bank (BDL) \\
\hline & W9 & $\begin{array}{l}\text { The number of KRUS pensions } \\
\text { beneficiaries per } 100 \text { people of } \\
\text { post-working age }\end{array}$ & W & 24.7 & $\begin{array}{l}\text { Agricultural Social } \\
\text { Insurance Fund (KRUS) } \\
\text { and the Local Data Bank } \\
\text { (BDL) }\end{array}$ \\
\hline \multirow{3}{*}{ 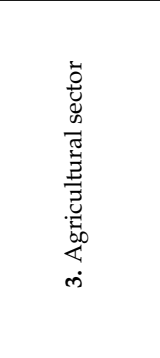 } & W10 & $\begin{array}{l}\text { The average size of farms (ha) owned by } \\
\text { direct payment applicants }\end{array}$ & M_W & 8.4 ha & $\begin{array}{c}\text { Agency for } \\
\text { Restructuring and } \\
\text { Modernisation of } \\
\text { Agriculture (ARiMR) }\end{array}$ \\
\hline & W11 & $\begin{array}{l}\text { Number of agricultural land parcels per } \\
100 \text { ha }\end{array}$ & M_W & 76.9 & $\begin{array}{c}\text { Agency for } \\
\text { Restructuring and } \\
\text { Modernisation of } \\
\text { Agriculture (ARiMR) }\end{array}$ \\
\hline & W12 & $\begin{array}{l}\text { The percentage of direct payment } \\
\text { applicants under the age of } 40 \text { years in the } \\
\text { total number of applicants }\end{array}$ & M_W & $25.5 \%$ & $\begin{array}{c}\text { Agency for } \\
\text { Restructuring and } \\
\text { Modernisation of } \\
\text { Agriculture (ARiMR) }\end{array}$ \\
\hline
\end{tabular}


Table A1. Cont.

\begin{tabular}{|c|c|c|c|c|c|}
\hline Components & Number of Indicator & Empirical Indicators & Spatial Unit ${ }^{a}$ & Median (2019) & Data Provider ${ }^{b}$ \\
\hline \multirow{3}{*}{ 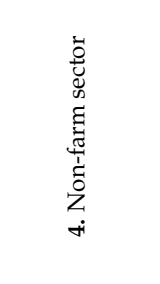 } & W13 & $\begin{array}{l}\text { The number of entities registered in the } \\
\text { REGON system per } 1000 \text { people of } \\
\text { working age }\end{array}$ & M_W & 124.9 & Local Data Bank (BDL) \\
\hline & W14 & $\begin{array}{l}\text { The number of PIT and CIT taxpayers } \\
\text { conducting business per } 1000 \text { inhabitants }\end{array}$ & M_W & 49.2 & $\begin{array}{l}\text { Ministry of Finance } \\
\text { (MF) and the Local Data } \\
\text { Bank (BDL) }\end{array}$ \\
\hline & W15 & $\begin{array}{l}\text { The percentage of public service operators } \\
\text { in the total number of entities registered in } \\
\text { the REGON system }\end{array}$ & M_W & $10.8 \%$ & Local Data Bank (BDL) \\
\hline \multirow{4}{*}{ 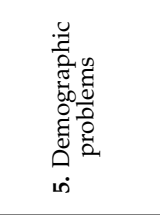 } & W21 & $\begin{array}{l}\text { The percentage of population of } \\
\text { post-working age }\end{array}$ & W & $19.2 \%$ & Local Data Bank (BDL) \\
\hline & W22 & $\begin{array}{l}\text { Feminisation ratio within the age range of } \\
25 \text { to } 34\end{array}$ & W & 92.2 & Local Data Bank (BDL) \\
\hline & W23 & Children-to-old-people ratio & W & 0.7 & Local Data Bank (BDL) \\
\hline & W24 & Population growth per 1000 inhabitants & W & -0.7 & Local Data Bank (BDL) \\
\hline \multirow{5}{*}{ 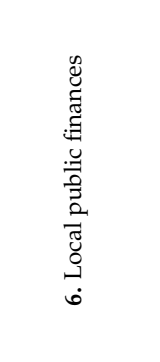 } & W16 & $\begin{array}{l}\text { Percentage of gmina's own income in total } \\
\text { income }\end{array}$ & M_W & $34 \%$ & Local Data Bank (BDL) \\
\hline & W17 & $\begin{array}{l}\text { The index value } G \text { used in the calculation } \\
\text { of compensatory subsidies }\end{array}$ & M_W & 65.9 & $\begin{array}{l}\text { Ministry of Finance } \\
\text { (MF) }\end{array}$ \\
\hline & W18 & $\begin{array}{l}\text { Gmina budget revenues from PIT and CIT } \\
\text { per capita }\end{array}$ & M_W & 576.8 PLN & Local Data Bank (BDL) \\
\hline & W19 & $\begin{array}{l}\text { Share of funds for financing and } \\
\text { co-financing of EU programmes and } \\
\text { projects within gmina revenue }\end{array}$ & M_W & $3.6 \%$ & Local Data Bank (BDL) \\
\hline & W20 & $\begin{array}{l}\text { The percentage of capital expenditure in } \\
\text { the general gmina's budget expenditures }\end{array}$ & M_W & $16.4 \%$ & Local Data Bank (BDL) \\
\hline \multirow{4}{*}{ 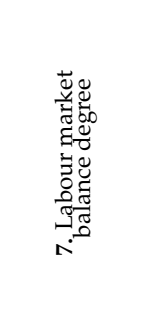 } & W25 & $\begin{array}{l}\text { The percentage of registered unemployed } \\
\text { among the working-age population }\end{array}$ & M_W & $4.1 \%$ & $\begin{array}{l}\text { Ministry of Labour and } \\
\text { Social Affairs (MPiPS) }\end{array}$ \\
\hline & W26 & Labour force aging ratio & W & 37.2 & Local Data Bank (BDL) \\
\hline & W27 & $\begin{array}{l}\text { The ratio of the migration attractiveness } \\
\text { for internal migration }\end{array}$ & W & -0.07 & Local Data Bank (BDL) \\
\hline & W28 & $\begin{array}{l}\text { Insured (individuals paying insurance } \\
\text { premiums) in KRUS (Agricultural Social } \\
\text { Insurance Fund) per } 100 \text { hectares of } \\
\text { farmland }\end{array}$ & W & 8.1 & $\begin{array}{c}\text { Agricultural Social } \\
\text { Insurance Fund (KRUS) } \\
\text { and Agricultural Social } \\
\text { Insurance Fund } \\
\text { (ARIMR) }\end{array}$ \\
\hline \multirow{5}{*}{ 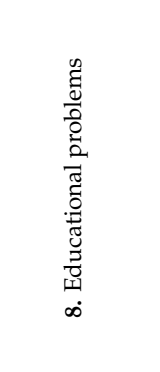 } & W29 & $\begin{array}{l}\text { The percentage of children attending } \\
\text { preschool in the } 3 \text { to } 5 \text { age group }\end{array}$ & M_W & $75.7 \%$ & Local Data Bank (BDL) \\
\hline & W30 & $\begin{array}{l}\text { Gross enrolment ratio at the primary } \\
\text { school level }\end{array}$ & M_W & 88.7 & Local Data Bank (BDL) \\
\hline & W31 & $\begin{array}{l}\text { The average primary school final test } \\
\text { result (score) }\end{array}$ & M_W & & $\begin{array}{l}\text { Central Examination } \\
\text { Commission (CKE) }\end{array}$ \\
\hline & W32 & $\begin{array}{l}\text { The average primary school final test } \\
\text { result-Maths and Polish }\end{array}$ & M_W & $50.7 \%$ & $\begin{array}{l}\text { Central Examination } \\
\text { Commission (CKE) }\end{array}$ \\
\hline & W33 & $\begin{array}{l}\text { The percentage of local council members } \\
\text { who are university or high-school } \\
\text { graduates }\end{array}$ & M_W & $73.3 \%$ & Local Data Bank (BDL) \\
\hline \multirow{6}{*}{ 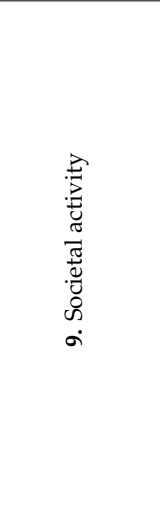 } & W34 & $\begin{array}{l}\text { Voter turnout in local elections (village } \\
\text { heads and mayors) }\end{array}$ & M_W & $55.8 \%$ & $\begin{array}{l}\text { National Electoral } \\
\text { Commission (PKW) }\end{array}$ \\
\hline & W35 & $\begin{array}{l}\text { Voter turnout in the presidential election } \\
\text { (first round) }\end{array}$ & M_W & $60.6 \%$ & $\begin{array}{l}\text { National Electoral } \\
\text { Commission (PKW) }\end{array}$ \\
\hline & W36 & $\begin{array}{l}\text { The number of NGOs per } 10,000 \\
\text { population }\end{array}$ & M_W & 33 & Local Data Bank (BDL) \\
\hline & W37 & $\begin{array}{l}\text { The percentage of PIT taxpayers donating } \\
1 \% \text { to non-profit organisations }\end{array}$ & W & $47.7 \%$ & $\begin{array}{l}\text { Ministry of Finance } \\
\text { (MF) }\end{array}$ \\
\hline & W38 & $\begin{array}{l}\text { The number of applications for funding of } \\
\text { projects co-financed by the European } \\
\text { Union for the years 2007-2013 per 10,000 } \\
\text { inhabitants }\end{array}$ & M_W & 80 & $\begin{array}{c}\text { Ministry of } \\
\text { Infrastructure and } \\
\text { Development (MIiR) }\end{array}$ \\
\hline & W39 & $\begin{array}{l}\text { The number of applications for funding of } \\
\text { projects under the LEADER initiative for } \\
2007-2013 \text { submitted via the LAGs per } \\
10,000 \text { inhabitants }\end{array}$ & M_W & 11 & 16 Offices of Marshals \\
\hline
\end{tabular}


Table A1. Cont.

\begin{tabular}{|c|c|c|c|c|c|}
\hline Components & Number of Indicator & Empirical Indicators & Spatial Unit $^{a}$ & Median (2019) & Data Provider $^{b}$ \\
\hline \multirow{5}{*}{ 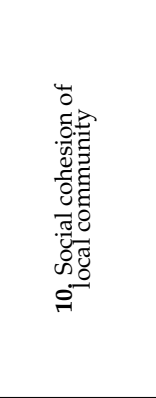 } & W40 & $\begin{array}{l}\text { The average annual income of a PIT } \\
\text { taxpayer }\end{array}$ & M_W & 35,220 PLN & $\begin{array}{l}\text { Ministry of Finance } \\
\text { (MF) }\end{array}$ \\
\hline & W41 & $\begin{array}{l}\text { The percentage of long-term unemployed } \\
\text { in the working-age population }\end{array}$ & M_W & $2 \%$ & $\begin{array}{l}\text { Ministry of Labour and } \\
\text { Social Affairs (MPiPS) }\end{array}$ \\
\hline & W42 & $\begin{array}{l}\text { The percentage of families covered by the } \\
\text { social welfare system in the general } \\
\text { population of a gmina }\end{array}$ & M_W & $6.1 \%$ & $\begin{array}{l}\text { Ministry of Labour and } \\
\text { Social Affairs (MPiPS) }\end{array}$ \\
\hline & W43 & $\begin{array}{l}\text { The number of dwellings with access to } \\
\text { internet service as a proportion of total } \\
\text { dwellings }\end{array}$ & W & $76.1 \%$ & $\begin{array}{l}\text { Office of Electronic } \\
\text { Communications (UKE) }\end{array}$ \\
\hline & W44 & $\begin{array}{l}\text { The average primary school final test } \\
\text { result in a foreign language }\end{array}$ & M_W & $49.4 \%$ & $\begin{array}{l}\text { Central Examination } \\
\text { Commission (CKE) }\end{array}$ \\
\hline \multirow{3}{*}{ 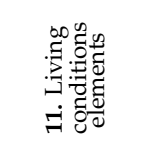 } & W45 & The percentage of flats with central heating & W & $69.7 \%$ & Local Data Bank (BDL) \\
\hline & W46 & $\begin{array}{l}\text { The percentage of permanently inhabited } \\
\text { flats with a flushable toilet }\end{array}$ & W & $87.1 \%$ & Local Data Bank (BDL) \\
\hline & W47 & Usable floor space per inhabitant & $\mathrm{W}$ & $28.5 \mathrm{~m}^{2}$ & Local Data Bank (BDL) \\
\hline
\end{tabular}

${ }^{\mathrm{a}}$ M_W-indicator for all gminas (in case of urban-rural gminas together with town); W-indicator for rural gminas and rural area in urban-rural gminas. ${ }^{b}$ Local Data Bank (BDL) under Central Statistical Office of Poland (GUS), Central Register of Vehicles and Drivers (CEPIK) under Ministry of the Interior and Administration, Agricultural Social Insurance Fund (KRUS), Agency for Restructuring and Modernisation of Agriculture (ARiMR), Central Examination Commission (CKE) which contains 8 District Examination Commissions, National Electoral Commission (PKW), Ministry of Finance (MF), Ministry of Labour and Social Affairs (MPiPS), Ministry of Infrastructure and Development (MIiR), Office of Electronic Communications (UKE), 16 Offices of Marshals, survey-Gmina Survey conducted in 2173 commune offices.

\section{References}

1. Myrdal, G. Economic Theory and Underdeveloped Regions; Gerald Duckworth \& Co.: London, UK, 1957.

2. Hirschman, A.O. The Strategy of Economic Development; Yale University Press: New Haven, CT, USA, 1958.

3. Friedmann, J. A General Theory of Polarized Development; The Ford Foundation: Santo Domingo, Chile, 1967.

4. Krugman, P. Development Geography, and Economic Theory; MIT Press: Cambridge, UK, 1995.

5. Iammarino, S.; Rodriguez-Pose, A.; Storper, M. Regional inequality in Europe: Evidence, theory and policy implications. J. Econ. Geogr. 2018, 19, 273-298. [CrossRef]

6. Woods, M. Rural Geography; Sage: London, UK, 2005.

7. Begg, I. Cohesion or Confusion: A Policy Searching for Objectives. Eur. Integr. 2010, 32, 77-96. [CrossRef]

8. OECD. Rural Well-Being: Geography of Opportunities, OECD Rural Studies; OECD Publishing: Paris, France, 2020; Available online: https:/ / www.oecd.org/regional/rural-well-being-d25cef80-en.htm (accessed on 1 June 2021).

9. Pahl, R.E. The rural-urban continuum. Sociol. Rural. 1966, 6, 299-329. [CrossRef]

10. European Union; FAO; UN-Habitat; OECD; The World Bank. Applying the Degree of Urbanisation-A Methodological Manual to Define Cities, Towns and Rural Areas for International Comparisons, 2021 ed.; Publications Office of the EU: Luxembourg, 2021. [CrossRef]

11. Saraceno, E. Disparity and Diversity: Their Use in EU Rural Policies. Sociol. Rural. 2013, 53, 331-348. [CrossRef]

12. Sherry, E.; Shortall, S. Methodological fallacies and perceptions of rural disparity: How rural proofing addresses real versus abstract needs. J. Rural Stud. 2018, 68, 336-343. [CrossRef]

13. OECD. OECD Principles on Urban Policy; OECD CFE: Paris, France, 2019; Available online: https://www.oecd.org/cfe/BrochureOECD-Principles-Urban-Policy.pdf (accessed on 1 June 2021).

14. Hoggart, K. Not a definition of rural. Area 1988, 20, 35-40.

15. Mormont, M. Who is rural? Or, how to be rural: Towards a sociology of the rural. In Rural Restructuring: Global Processes and Their Responses; Marsden, T., Lowe, P., Whatmore, S., Eds.; David Fulton: London, UK, 1990; pp. 21-44.

16. Halfacree, K.H. Locality and social representation: Space, discourse and alternative definitions of the rural. J. Rural. Stud. 1993, 9, 23-37. [CrossRef]

17. Cloke, P.J. Rural life-styles: Material opportunity, cultural experience, and how theory can undermine policy. Econ. Geogr. 1996, 72, 433-449. [CrossRef]

18. Cromartie, J.; Bucholtz, S. Defining the "rural" in rural America. Amber Waves 2008, 6, 3.

19. FAO. Guidelines on Defining Rural Areas and Compiling Indicators for Development Policy. 2018. Available online: http: / / www.fao.org/3/ca6392en/ca6392en.pdf (accessed on 15 June 2021).

20. UNSD. A Recommendation on the Method to Delineate Cities, Urban and Rural Areas for International Statistical Comparisons. 2020. Available online: https://unstats.un.org/unsd/statcom/51st-session/documents/BG-Item3j-Recommendation-E.pdf (accessed on 25 May 2021).

21. Cloke, P.J. An index of rurality for England and Wales. Reg. Stud. 1977, 11, 31-46. [CrossRef] 
22. Halfacree, K.H. Talking about rurality: Social representations of the rural as expressed by residents of six English parishes. J. Rural. Stud. 1995, 11, 1-20. [CrossRef]

23. Isserman, A.M. In the national interest: Defining rural and urban correctly in research and public policy. Int. Reg. Sci. Rev. 2005, 28, 465-499. [CrossRef]

24. Nelson, K.S.; Nguyen, T.D.; Brownstein, N.A.; Garcia, D.; Walker, H.C.; Watson, J.T.; Xin, A. Definitions, measures, and uses of rurality: A systematic review of the empirical and quantitative literature. J. Rural Stud. 2021, 82, 351-365. [CrossRef]

25. Rodríguez-Pose, A. The revenge of the places that don't matter (and what to do about it). Camb. J. Reg. Econ. Soc. 2018, 11, 189-209. [CrossRef]

26. Edensor, T.; Kalandides, A.; Kothari, U. (Eds.) The Routledge Handbook of Place; Routledge: Abingdon, UK; New York, NY, USA, 2020.

27. Rye, J.F. Rural youths' images of the rural. J. Rural Stud. 2006, 22, 409-421. [CrossRef]

28. Brezzi, M.; Dijkstra, L.; Ruiz, V. OECD Extended Regional Typology: The Economic Performance of Remote Rural Regions. OECD Reg. Dev. Work. Pap. 2011, 6, 1-21. [CrossRef]

29. Pain, A.; Hansen, K. Rural Development; Routledge: Abingdon, UK, 2019.

30. Halamska, M. Continuity and Change. Rural Poland 1918-2018; Searching for Sources of the Present, IRWiR PAN; Scholar Publishing House Ltd:: Warsaw, Poland, 2020.

31. OECD. Rural 3.0. Policy Note-A Framework for Rural Development; OECD: Paris, France, 2018; Available online: https://www oecd.org/cfe/regional-policy/Rural-3.0-Policy-Note.pdf (accessed on 1 June 2021).

32. Stanny, M. Wieś, obszar wiejski, ludność wiejska-O problemach z ich definiowaniem. Wielowymiarowe spojrzenie. WiR 2014, $162,123-138$.

33. Sorokin, P.A.; Zimmerman, C.C. Principles of Rural-Urban Sociology; Henry Holt and Co.: New York, NY, USA, 1929.

34. Cloke, P.; Edwards, G. Rurality in England and Wales 1981: A replication of the 1971 index. Reg. Stud. 1986, 4, 289-306. [CrossRef]

35. Harrington, V.; O'Donoghue, D. Rurality in England and Wales 1991: A Replication and Extension of the 1981 Rurality Index. Sociol. Rural 1998, 38, 178-203. [CrossRef]

36. Prieto-Lara, E.; Ocaña-Riola, R. Updating Rurality Index for Small Areas in Spain. Soc. Indic. Res. 2010, 95, 267-280. [CrossRef]

37. Salvati, L.; Zitti, M.; Carlucci, M. In-between regional disparities and spatial heterogeneity: A multivariate analysis of territorial divides in Italy. J. Environ. Plan. Manag. 2016, 60, 997-1015. [CrossRef]

38. Li, Y.; Long, H.; Liu, Y. Spatio-temporal pattern of China's rural development: A rurality index perspective. J. Rural Stud. 2015, 38, 12-26. [CrossRef]

39. Waldorf, B.; Kim, A. The Index of Relative Rurality (IRR): US County Data for 2000 and 2010. Purdue Univ. Res. Repos. 2018. [CrossRef]

40. Nestorová Dická, J.; Gessert, A.; Sninčák, I. Rural and non-rural municipalities in the Slovak Republic. J. Maps 2019, 15, 84-93. [CrossRef]

41. Woods, M.; Heley, J. Conceptualisation of Rural-Urban Relations and Synergies. Deliverable 1.1. In ROBUST Project Report; Department of Geography and Earth Sciences: Aberystwyth, UK, 2017; Available online: https:/ /rural-urban.eu/publications / conceptualisation-rural-urban-relations-and-synergies (accessed on 26 May 2021).

42. Murdoch, J.; Pratt, A.C. Rural studies: Modernism, postmodernism and the 'post-rural'. J. Rural Stud. 1993, 9, 411-427. [CrossRef]

43. Hedlund, M. Mapping the Socioeconomic Landscape of Rural Sweden: Towards a Typology of Rural Areas. Reg. Stud. 2016, 50, 460-474. [CrossRef]

44. Cattivelli, V. Methods for the identification of urban, rural and peri-urban areas in Europe: An overview. J. Urban Regen. Renew. 2021, 14, 240-246.

45. Nowak, S. Methodology of Sociological Research; Springer: Dordrecht, The Netherlands, 1977.

46. Hartigan, J.A. Clustering Algorithms; John Wiley and Sons: New York, NY, USA, 1975.

47. Kaufman, L.; Rousseeuw, P.J. Finding Groups in Data: An Introduction to Cluster Analysis; John Wiley \& Sons: New York, NY, USA, 1990.

48. Murtagh, F.; Legendre, P. Ward's Hierarchical Agglomerative Clustering Method: Which Algorithms Implement Ward's Criterion? J. Classif. 2014, 31, 274-295. [CrossRef]

49. Gülagiz, F.K.; Sahin, S. Comparison of Hierarchical and Non-Hierarchical Clustering Algorithms. Int. J. Comput. Eng. Inf. Technol. 2017, 9, 6-14.

50. MacQueen, J. Some methods for classification and analysis of multivariate observations. In Proceedings of the 5th Berkeley Symposium on Mathematical Statistics and Probability, the Statistical Laboratory, University of California, Oakland, CA, USA, 21 June-18 July 1965; Le Cam, L.M., Neyman, J., Eds.; University of California Press: Berkeley, CA, USA, 1967; pp. $281-297$.

51. Murtagh, F.; Heck, A. Multivariate Data Analysis; D. Reidel Publishing Co.: Dordrecht, The Netherlands, 1987.

52. Imaizumi, T.; Okada, A.; Miyamoto, S.; Sakaori, F.; Yamamoto, Y.; Vichi, M. (Eds.) Advanced Studies in Classification and Data Science; Springer: Singapore, 2020.

53. Copus, A.; Psaltopoulos, D.; Skuras, D.; Terluin, I.; Weingarten, P. Approaches to Rural Typology in the European Union. JRC Sci. Tech. Rep. 2008, 48464, 47-54.

54. Weingarten, P.; Copus, A.; Psaltopoulos, D.; Skuras, D.; Terluin, I. Typology of European Rural Areas for Spatial Impact Assessment of Policies. JRC Sci. Tech. Rep. 2010, 58493. 
55. Hopkins, J.; Copus, A. Definitions, Measurement Approaches and Typologies of Rural Areas and Small Towns: A Review; The James Hutton Institute: Aberdeen, UK, 2018.

56. Perlín, R.; Kucerova, S.; Kucera, Z. A typology of rural space in Czechia according to its potential for development. Geografie 2010, 115, 161-187. [CrossRef]

57. Klufová, R. Current Delimitation and Typology of the Czech Countryside and its Importance for Rural Development. East. Eur. Countrys. 2016, 22, 229-251. [CrossRef]

58. Mikhaylova, S.; Budazhanayeva, M.T.; Sarycheva, T.V.; Bakumenko, L.P. Typology of Rural Territories of the Russian Federation Subjects. Mediterr. J. Soc. Sci. 2015, 6, 205-212. [CrossRef]

59. Bański, J.; Mazur, M. Classification of rural areas in Poland as an instrument of territorial policy. Land Use Policy 2016, 54, 1-17. [CrossRef]

60. SYKE. Urban-Rural Classification. 2020. Available online: https://www.ymparisto.fi/en-US/Living_environment_and_ planning/Community_structure/Information_about_the_community_structure/Urbanrural_classification (accessed on 4 June 2021).

61. Gajić, A.; Krunić, N.; Protić, B. Classification of Rural Areas in Serbia: Framework and Implications for Spatial Planning. Sustainability 2021, 13, 1596. [CrossRef]

62. Van Eupen, M.; Metzger, M.J.; Pérez-Soba, M.; Verburg, P.H.; Van Doorn, A.; Bunce, R.G.H. A rural typology for strategic European policies. Land Use Policy 2012, 29, 473-482. [CrossRef]

63. Wiggins, S.; Proctor, S. How special are rural areas? The economic implications of locations for rural development. Dev. Policy Rev. 2001, 19, 427-436. [CrossRef]

64. Santacroce, P. Atlante dei Comuni d'Italia: Relativo Alle Modifiche Edilizio-Abitative ed Agricole Negli Anni Settanta e Primi Anni Ottanta; Franco Angeli: Milan, Italy, 1989.

65. Andrychowicz, B.; Conte, A.; Frenkel, I.; Rosner, A.; Santacroce, P. Atlas Demograficzny i Społeczno-Zawodowy Obszarów Wiejskich w Polsce, PTD; IRWiR PAN: Warsaw, Poland, 1995.

66. OECD. Rural Policy Reviews: Poland 2018; OECD Publishing: Paris, France, 2018; Available online: https: / /www.oecd-ilibrary.org/ urban-rural-and-regional-development/oecd-rural-policy-reviews-poland-2018_9789264289925-en (accessed on 1 June 2021).

67. Freshwater, D. The importance of improving incentives and employment opportunities for farm households in Poland. WiR 2017, 176, 11-33. [CrossRef]

68. Rosner, A.; Stanny, M. Rozważania o pojęciu i procesie dezagraryzacji polskiej wsi. WiR 2018, 2, 281-292. [CrossRef]

69. Gorlach, K.; Starosta, P. De-peasantisation or repeasantisation? Changing rural social structures in Poland after World War II. In Europe's Green Ring; Granberg, I., Kovách, I., Tovey, H., Eds.; Ashgate Publishing: Farnham, UK, 2001; pp. $42-66$.

70. Local Data Bank of Statistics Poland (BDL GUS). Available online: https:/ /bdl.stat.gov.pl/BDL/start (accessed on 1 June 2021).

71. Henningsen, A. Why is the Polish farm sector still so underdeveloped? Post Communist Econ. 2009, 21, 47-64. [CrossRef]

72. Halamska, M. The evolution of family farms in Poland: Present time and the weight of the past. East. Eur. Countrys. 2016, 22, 27-51. [CrossRef]

73. Rosner, A.; Stanny, M. Socio-Economic Development of Rural Areas in Poland; EFRWP; IRWiR PAN: Warsaw, Poland, 2017; Available online: http:/ / www.irwirpan.waw.pl/dir_upload/site/files/Lukasz/MROW_en_2017.pdf (accessed on 4 July 2021).

74. Stanny, M.; Rosner, A.; Komorowski, Ł. Monitoring Rozwoju Obszarów Wiejskich. Etap III. Struktury Społeczno-Gospodarcze, Ich Przestrzenne Zróżnicowanie i Dynamika; EFRWP; IRWiR PAN: Warsaw, Poland, 2018.

75. Sneath, P.H.A.; Sokal, R.R. Numerical Taxonomy: The Principles and Practice of Numerical Classification; W.H. Freeman and Co.: San Francisco, CA, USA, 1973.

76. Parysek, J.J.; Wojtasiewicz, L. Metody Analizy Regionalnej i Metody Planowania Regionalnego; PWN: Warsaw, Poland, 1979.

77. Kukuła, K.; Bogocz, D. Zero unitarization method and its application in ranking research in agriculture. Econ. Reg. Stud. 2014, 7, 5-13.

78. Wang, B.; Zhang, S. A Subjective and Objective Integration Approach of Determining Weights for Trustworthy Measurement. IEEE Access 2018, 6, 25829-25835. [CrossRef]

79. Diday, E. The dynamic clusters method in nonhierarchical clustering. Int. J. Comput. Inf. Sci. 1973, 2, 61-88. [CrossRef]

80. Liberti, L.; Lavor, C. Euclidean Distance Geometry: An Introduction; Springer: Cham, Switzerland, 2017.

81. Siegel, S.; Castellan, N.J. Nonparametric Statistics for the Behavioral Sciences; McGraw-Hill: New York, NY, USA, 1988.

82. Abdi, H. Kendall rank correlation. In Encyclopedia of Measurement and Statistics; Salkind, N.J., Ed.; SAGE Publications: Thousand Oaks, CA, USA, 2007.

83. Stasiak, A.; Mirowski, W. (Eds.) The processes of depopulation of rural areas in central and eastern europe. In Proceedings of the International Seminar on Rural Depopulation, Szymbark, Poland, September 1989; Institute of Geography and Spatial Organization Polish Academy of Sciences: Warsaw, Poland, 1990.

84. Stanny, M. Spatial diversification of the balance on the labour market in rural areas in Poland. Bull. Geography. Socio-Econ. Ser. 2010, 14, 103-111. [CrossRef]

85. Wandycz, P.S. The Lands of Partitioned Poland, 1795-1918; A History of East Central Europe; University of Washington Press: Washington, WA, USA, 1974; Volume 7.

86. Koryś, P. Poland from Partitions to EU Accession: A Modern Economic History, 1772-2004; Palgrave Macmillan: Cham, Switzerland, 2018. 
87. Stanny, M.; Rosner, A.; Kozdron, E. Changes in the Spatial Distribution of the Level and Dynamics of Socio-Economic Development of Rural Areas in Poland. WiR 2016, 4, 29-47. [CrossRef]

88. Gorlach, K. The peasant issue in contemporary Poland. Pol. Sociol. Rev. 1995, 110, 139-158.

89. Rosner, A.; Wesołowska, M. Deagrarianisation of the Economic Structure and the Evolution of Rural Settlement Patterns in Poland. Land 2020, 9, 523. [CrossRef]

90. Binder, P. Młodzi a Bieda: Strategie Radzenia Sobie w Doświadczeniu Młodego Pokolenia Wsi Pokołchozowych i Popegeerowskich; IFiS PAN: Warsaw, Poland, 2014.

91. Tarkowska, E. Poverty and education risk of "inheritance" of poverty in the former state farms in Poland. Pol. Sociol. Rev. 2002, 138, 203-215.

92. Rosner, A. Migracje Wieś-Miasto a Przepływy Między Typami Gospodarstw Domowych Ludności Wiejskiej; IRWiR PAN: Warsaw, Poland, 1991.

93. Okólski, M. Spatial mobility from the perspective of the incomplete migration concept. Cent. East. Eur. Migr. Rev. 2012, 1, 11-35.

94. Kołodziejczak, A.; Kacprzak, E.; Maćkiewicz, B. Problemy rolnictwa na obszarach metropolitalnych. Rozw. Reg. Polityka Reg. 2019, 47, 37-56. [CrossRef]

95. Zwęglińska-Gałecka, D. Gentryfikacja wsi i jej zasięg. WiR 2019, 2, 57-87. [CrossRef]

96. Cattivelli, V. Institutional Methods for the Identification of Urban and Rural Areas-A Review for Italy. Smart Sustain. Plan. Cities Reg. 2019, 187-207. [CrossRef]

97. OECD. Principles on Urban Policy and on Rural Policy. In Megatrends: Building Better Futures for Regions, Cities and Rural Area; OECD Regional Development Ministerial: Athens, Greece, 2019; Available online: https://www.oecd.org/regional/ministerial/ documents/urban-rural-Principles.pdf (accessed on 1 June 2021).

98. SHERPA. Long-Term Vision for Rural Areas: Contribution from 20 Science-Society-Policy Platforms, SHERPA Discussion Paper. 2020. Available online: https://rural-interfaces.eu/wp-content/uploads/2020/11/SHERPA_Discussion-Paper_Long-termvision-rural-areas.pdf (accessed on 30 June 2021).

99. EC. A Long-Term Vision for the EU's Rural Areas-Towards Stronger, Connected, Resilient and Prosperous Rural Areas by 2040 ; COM 345 Final; EC: Brussels, Belgium, 2021.

100. Li, Y.; Westlund, H.; Liu, Y. Why some rural areas decline while some others not: An overview of rural evolution in the world. J. Rural Stud. 2019, 68, 135-143. [CrossRef]

101. ESPON. ESCAPE_European Shrinking Rural Areas: Challenges, Actions and Perspectives for Territorial Governance. Applied Research. Synthesis Report. 2020. Available online: https:/ /www.espon.eu/escape (accessed on 1 July 2021).

102. MFiPR. Wpływ Polityki Spójności na Rozwój Obszarów Wiejskich; MFiPR: Warsaw, Poland, 2019.

103. Rosner, A.; Stanny, M.; Komorowski, Ł. Zróżnicowanie Przestrzenne Poziomu Rozwoju Społeczno-Gospodarczego Obszarów Wiejskich Wielkopolski Oraz Ich Pozycja na tle Obszarów Wiejskich Kraju; WROT UMWW: Poznań, Poland, 2018. 